\title{
PENGARUH MOTIVASI DAN DISIPLIN KERJA TERHADAP KINERJA KARYAWAN DI MANAGEMENT OFFICE RESINDA PARK MALL KARAWANG
}

\author{
THE INFLUENCE'S MOTIVATION AND WORK DISCIPLINE \\ ON EMPLOYEE PERFORMANCE \\ IN THE MANAGEMENT OFFICE RESINDA PARK MALL \\ KARAWANG
}

\author{
Windi Widyalova ${ }^{1}$ Budi Rismayadi $^{2}{\text { Flora } \text { Patricia }^{3}}^{3}$ \\ budi.rismayadi@ubpkarawang.ac.id \\ Universitas Buana Perjuangan Karawang
}

\begin{abstract}
ABSTRAK
Penelitian ini bertujuan untuk memperoleh bukti-bukti empirik dan menemukan kejelasan fenomena serta kesimpulan tentang pengaruh Motivasi Kerja Terhadap Kinerja Karyawan dan Pengaruh Disiplin Kerja Terhadap Kinerja Karayawan di Management Office Resinda Park Mall Karawang secara simulatan dan parsial. Dengan populasi sebanyak 115 orang yang seluruhnya digunakan sebagai sampel dalam penelitian ini. Teknik pengambilan sampel yang digunakan adalah teknik Random Sampling. Penelitian dilakukan dengan menggunakan metode kuantitatif dengan jenis penelitian deskriptif yaitu dengan pengumpulan hasil kuesioner. Dari hasil analisis data penelitian, diperoleh kesimpulan bahwa Berdasarkan analisis deskriptif, Motivasi Kerja mendapatkan skala baik karena memiliki rata-rata 471 pada rentang skala 391-483. maka secara keseluruhan motivasi pada Management Office Resinda Parrk Mall sudah termasuk dalam kategori yang baik. 2. Berdasarkan analisis deskriptif, Disiplin Kerja mendapatkan skala baik karena memiliki nilai rata-rata sebesar 475, maka secara keseluruhan disiplin kerja pada Management Office Resinda Park Mall sudah termasuk dalam kategori yang sangat baik. 3. Berdasarkan analisis deskriptif, Kinerja Karyawan mendapatkan skala baik karena memiliki nilai rata-rata sebesar 476 maka secara keseluruhan Kinerja Karyawan di Management Office Resinda Park Mall sudah termasuk dalam kategori yang baik.
\end{abstract}

Kata Kunci: Motivasi Kerja, Disiplin Kerja, Kinerja Karyawan 


\begin{abstract}
This study aims to obtain empirical evidence and find clarity of phenomena and conclusions about the influence of Work Motivation on Employee Performance and the Effect of Work Discipline on Performance of Karayawan in the Management Office of Karawang Mall Mall Resinda simulatanally and partially. With this study population 115 people and the number of samples used are 115 employees in the Management Office Resinda Park Mall Karawang. The sampling technique used is the Random Sampling technique. The study was conducted using quantitative methods with the type of descriptive research is by collecting the results of the questionnaire. From the results of the analysis of research data, the following conclusions are obtained:

1. Based on descriptive analysis, Work Motivation get a good scale because it has an average of 471 in the scale range 391-483. then overall motivation in the Management Office of the Mall Parrk Resinda is included in the good category.

2. Based on descriptive analysis, Work Discipline gets a good scale because it has an average value of 475, so overall work discipline in the Management Office of Resinda Park Mall is included in the excellent category.

3. Based on descriptive analysis, Employee Performance gets a good scale because it has an average value of 476 then overall Employee Performance at Resinda Park Mall Management Office is included in a good category.
\end{abstract}

\title{
Keywords: Work Motivation, Work Discipline, Employee Performance
}

\section{Pendahuluan}

Setiap perusahaan sangat membutuhkan sumber daya manusia yang berkualitas untuk mencapai tujuan perusahaan yang sudah di tentukan. Dalam pencapaian tujuan tersebut maka suatu perusahaan membutuhkan seorang pemimpin yang mampu mengelola sumber daya manusia yang ada di dalam perusahaan tersebut yaitu untuk meningkatkan kinerja karyawan secara efisien, dan efektif kerja didalam suatu perusahaan. Untuk mencapai tujuan perusahan maka pemimpin atau 
manajer akan memberikan sebuah tugas pada setiap karyawan sesuai dengan fungsi dan jabatan masing-masing dalam peusahaan. Tugas yang di berikan pemimpin atau manajer bagi karyawan merupakan sebuah tanggung jawab yang harus di laksanakan secara tulus dan dengan sungguh-sungguh agar tercapai tujuan perusahaan yang telah di tentukan. Untuk mendapatkan kinerja karyawan yang sesuai dengan yang diharapkan, perusahaan mempunyai tugas untuk memberikan dorongan kepada para karyawan agar mereka bekerja dengan giatnya sehingga mencapai target perusahaan. Secara teori berbagai definisi tentang motivasi biasanya terkandung keinginan, harapan, kebutuhan, tujuan, sasaran, dorongan, dan insentif. Karyawan bekerja dengan harapan agar memperoleh upah yang dapat memenuhi kebutuhannya.

Dorongan seseorang untuk bekerja dipengaruhi adanya kebutuhan yang harus dipenuhi dan tingkat kebutuhan yang berbeda pada setiap karyawan, sehingga dapat terjadi perbedaan motivasi dalam berprestasi. Selain itu, pemenuhan kebutuhan dari para karyawan akan pelayanan dan penghargaan oleh atasan terhadap prestasi kerja yang dihasilkan sesuai dengan prinsip keadilan dapat memotivasi kerja karyawan. Mengingat pentingnya motivasi kerja karyawan dalam mencapai tujuan organisasi perusahaan, maka perlu diupayakan agar motivasi karyawan lebih ditingkatkan lagi. Karyawan yang mempunyai motivasi yang tinggi biasanya mempunyai catatan kehadiran yang lebih baik serta mempunyai prestasi yang lebih baik dibandingkan karyawan yang tidak termotivasi dalam kerjanya. Karyawan yang tidak pernah mencapai kondisi tersebut maka tidak pernah mencapai kematangan psikologi dan pada gilirannya akan menurukan semangat kerja, mudah menyerah, dan kesulitan dalam menyelesaikan pekerjaannya. Untuk menciptakan kinerja karyawan agar berjalan dengan efektif, hal tersebut tidak hanya didorong dengan adanya motivasi saja, tetapi dengan mempunyai disiplin kerja yang tinggi.

Hal ini mendorong gairah kerja, semangat kerja, dan terwujudnya tujuan perusahaan, karyawan dan masyarakat. Oleh karena itu, setiap manajer selalu berusaha agar para bawahannya mempunyai disiplin yang baik. Seorang manajer dikatakan efektif dalam kepemimpinannya, jika para bawahannya berdisiplin baik. Untuk memelihara dan meningkatkan kedisiplinan yang baik adalah hal yang sulit, karena banyak faktor yang mempengaruhinya. Indikator disiplin kerja adalah: 
mematuhi semua peraturan perusahaan, penggunaan waktu secara efektif, tanggung jawab dalam pekerjaan dan tugas serta tingkat absensi. Agar perusahaan mampu terus bertahan dan bersaing, maka perusahaan harus meningkatkan kualitas dan kuantitas karyawan demi mempertahankan pelayanan terbaik yang dihasilkannya.

Dalam hal ini penulis akan memilih Management Office Resinda Park Mall sebagai salah satu objek penelitian, yang bertempat di Jl. Resinda Raya No.2, Desa Purwadana, Kecamatan Teluk Jambe Timur, Karawang Barat, Jawa Barat. 41361. Resinda Park Mall merupakan pusat perbelanjaan yang keberadaannya di PT. Bukit Muria Jaya Estate dan menjadi bagian dari sejarah dibentuknya PT. Bukit Muria Jaya Estate. Resinda Park Mall berdiri sejak 25 Maret 2017 yang berstatus dalam naungan perusahaan Bukit Muria Jaya Estate yang beralamat di Jl. Resinda Raya No.2, Desa Purwadana, Kecamatan Teluk Jambe Timur, Karawang Barat, Jawa Barat. 41361. Merupakan pusat perbelanjaan yang keberadaannya di PT. Bukit Muria Jaya Estate dan menjadi bagian dari sejarah dibentuknya PT. Bukit Muria Jaya Estate. Kabupaten Karawang merupakan salah satu kabupaten yang memiliki tingkat produktivitas padi terbesar di Jawa Barat, dengan letak yang strategis serta lahan luas dan posisi yang dekat dengan DKI Jakarta. Karawang saat ini telah mengalami pembangunan dan perkembangan dalam bidang industri manufaktur. Idealnya, pertumbuhan ini didukung dengan penyediaan sumber daya manusia (SDM) yang baik dari berbagai multi-disiplin ilmu.

Kabupaten Karawang adalah daerah penghasil padi yang dikenal sebagai "Kota Pangkal Perjuangan" dan sebagai daerah "Lumbung Padi” karena penduduknya yang bermata pencaharian sebagai petani. Namun seiring berjalannya waktu serta perkembangan industri yang sangat pesat serta pergeseran pola pembangunan dan kebijakan yang lebih mengarah ke sektor riil, mengakibatkan terjadinya alih fungsi tata guna lahan di Kabupaten Karawang yang membuat Kabupaten Karawang sekarang ini lebih dikenal sebagai Kota Industri sehingga banyak mengundang pendatang baru dari berbagai kota, atau bahkan dari luar negri yang mencari kerja dan menetap tinggal di Kabupaten Karawang ini. Hal ini dapat dilihat dengan semakin berkembangnya Karawang sebagai salah satu kota dengan jumlah kawasan industri yang terbanyak di Indonesia seperti Karawang International City (KIIC), Suryacipta, Kawasan Industri Mitra, dan sebagainya. Kebutuhan ke arah 
peningkatan kota industri berakibat kepada kebutuhan tenaga kerja yang meningkat. Hal ini dapat berimbas terhadap peningkatan tenaga kerja dan peningkatan jumlah pendatang ke Kabupaten Karawang sebagai tenaga kerja. Dampak dari hal tersebut adalah peningkatan populasi di Kabupaten Karawang yang membutuhkan pembangunan infrastruktur dan fasilitas kebutuhan masyarakat (lokal dan pendatang). Selain membutuhkan peningkatan infrastruktur dan fasilitas, pengingkatan populasi penduduk perlu ditunjang oleh objek wisata serta pusat perbelanjaan modern yang memadai. Peningkatan jumlah penduduk di Kabupaten Karawang akan memberikan dampat positif dan negatif. Dampak positif yang mungkin timbul seperti berkembangnya kegiatan ekonomi masyarakat, sedangkan dampak negatif yang akan timbul yaitu alih guna lahan pertanian bahkan pesisir/pantai. Kabupaten Karawang menghadirkan pusat perbelanjaan terbesar dan termegah yaitu Resinda Park Mall, Resinda Park Mall didasari oleh proyek perusahaan Bukit Muria Jaya Estate atau bisa disebut Resinda Group, serta dilihat dari kebutuhan para penghuni Perumahan resinda yang membutuhkan suatu tempat untuk berbelanja seperti kebutuhan sandang, pangan, papan, serta kebutuhan hiburan jasmani dan rohani. Guna mempermudah para penghuni Perumahan Resinda agar tidak perlu berpergian jauh dari rumah untuk membeli kebutuhannya, maka dibangunlah sebuah Mall yang diberi nama Resinda Park Mall.

Resinda Park Mall adalah salah satu tempat berbelanja yang menyediakan fasilitas seperti Cinema, Restaurants, dan fasilitas entertainment. Resinda Park Mall adalah mall berkelas menengah atas yang pertama di Kabupaten Karawang dengan berbagai lebel bermerek dan ternama. Selain mengenalkan beberapa merek ternama, Resinda Park Mall juga telah menjadi salah satu ikon di Kota Karawang dengan arsitektur gedungnya yang mewah dengan kubah ditengah atrium nya yang membuat Resinda Park Mall menjadi ikon di Kabupaten Karawang. Sejak awal berdirinya Resinda Park Mall salah satu tujuannya adalah mampu bertahan dengan memberikan pelayanan terbaik.

Sehingga fakto-faktor yang dapat menjadi pendukung tercapainya tujuan perusahaan menjadi perhatian besar bagi perusahaan, salah satunya adalah keberadaan sumber daya manusia beserta hal-hal yang mampu meningkatkan kinerja perusahaan. Motivasi dan disiplin kerja adalah diantaranya. 
Maka untuk meningkatkan kualitas dan kuantitas hasil kerja karyawan idealnya dengan memberi motivasi secara terus menerus kepada mereka. Pemberian motivasi dapat berupa memberi penghargaan atas produktivitas mereka masingmasing berdasarkan penilaian yang dilakukan kepada setiap karyawan. Dengan demikian karyawan akan termotivasi untuk melaksanakan tugasnya dengan baik, sehingga kualitas dan kuantitas hasil kerjanya diharapkan dapat meningkat. Semakin baik kinerja yang dihasilkan para karyawan maka semakin baik pula efektifitas pemberian pelayanan sehingga akan meningkatkan keuntungan dan kepercayaan dari pelanggan.

Beberapa fenomena lain yang dapat ditemukan terkait hubungannya dengan motivasi dan disiplin kerja karyawan di Management Office Resinda Park Mall Karawang diantaranya adalah, adanya hubungan yang kurang harmonis sesama pegawai, ketidak puasan terhadap atasan, kedisiplinan yang masih belum di aplikasikan oleh beberapa pegawai, belum optimalnya penilaian prestasi kerja karyawan, menurunnya kinerja karyawan di Management Office Resinda Park Mall Karawang.

Penilaian prestasi kerja karyawan sangat penting kegunaannya terutama untuk penentuan kebijakan-kebijakan seperti pemberian peningkatan tunjangan. Sebagian karyawan kurang mengetahui adanya dan kegunaan penilaian tersebut, sehingga dapat dikatakan bahwa penilaian prestasi tampaknya masih belum secara optimal meningkatkan motivasi dan kinerja.turunnya disiplin kerja ditandai dengan tingginya absensi, dan keterlambatan.

Berdasarkan uraian diatas maka penulis tertarik untuk memilih dan membahas masalah motivasi dan disiplin kerja terhadap kinerja karyawan secara umum di Management Office Resinda Park Mall Karawang dalam rangka merumuskan kebijaksaan yang berkaitan dengan upaya membina meningkatkan kinerja karyawan.

\subsection{Rumusan Masalah}

Berdasarkan latar belakang penelitian diatas maka diidentifikasikan masalahnya adalah sebagai berikut :

1. Bagaimana motivasi kerja karyawan Management Office Resinda Park Mall ? 
2. Bagaimana disiplin kerja karyawan Management Office Resinda Park Mall ?

3. Bagaimana kinerja karyawan Management Office Resinda Park Mall ?

4. Bagaimana pengaruh motivasi kerja terhadap kinerja karyawan Management Office Resinda Park Mall ?

5. Bagaimana pengaruh disiplin kerja terhadap kinerja karyawan Management Office Resinda Park Mall ?

6. Bagaimana pengaruh motivasi kerja dan disiplin kerja terhadap kinerja karyawan Management Office Resinda Park Mall?

\subsection{Tujuan Penelitian}

Berdasarkan perumusan masalah diatas, peneliti mempunyai tujuan sebagai berikut :

1. Untuk mengetahui, menganalisis dan mengkaji motivasi kerja karyawan Management Office Resinda Park Mall.

2. Untuk mengetahui, menganalisis dan mengkaji disiplin kerja karyawan Management Office Resinda Park Mall.

3. Untuk mengetahui, menganalisis dan mengkaji kinerja karyawan Management Office Resinda Park Mall.

4. Untuk mengetahui, menganalisis dan mengkaji pengaruh motivasi kerja terhadap kinerja karyawan Management Office Resinda Park Mall.

5. Untuk mengetahui, menganalisis dan mengkaji pengaruh disiplin kerja terhadap kinerja karyawan Management Office Resinda Park Mall.

6. Untuk mengetahui, menganalisis dan mengkaji pengaruh motivasi dan disiplin kerja terhadap kinerja karyawan Management Office Resinda Park Mall.

\section{Tinjauan Pustaka}

\subsection{Motivasi}

Gray (dalam Winardi 2011:2) “mendefinisikan motivasi sebagai hasil sejumlah proses yang bersifat internal atau eksternal bagi seorang individu, yang menyebabkan timbulnya sikap antusiasme dan persistence dalam hal melaksanakan kegiatan-kegiatan tertentu". Stefan Ivanko (2012:7) “mendefinisikan motivasi sebagai keinginan dan energi seseorang yang diarahkan untuk pencapaian suatu 
tujuan. Motivasi adalah sebab dari tindakan. Upaya mempengaruhi seseorang dalam rangka memberikan motivasi berarti mendapatkan kemudian ingin berbuat sesuatu yang di ketahui dan seharusnya dilakukan. Motivasi dapat berupa motivasi intrinsik dan motivasi ekstrinsik. Motivasi intrinsik contohnya kepuasan dan perasaan untuk mencapai sesuatu. Motivasi ekstrinsik contohnya imbalan, hukuman, dan perolehan tujuan".

Dari definisi diatas peneliti mengambil kesimpulan bahwa motivasi adalah suatu keinginan dan tindakan yang muncul dalam diri seseorang atas dorongan untuk melakukan sesuatu dalam upaya mencapai tujuannya.

\subsection{Disiplin Kerja}

Pengertian disiplin kerja menurut Mangkunegara (2013:129) adalah kegiatan manajemen untuk memperteguh pedoman-pedoman organisasional.

Berikut defisini disiplin kerja menurut beberapa para ahli yang penulis susun yaitu diantaranya :

Hasibuan (2012:193) “mendefinisikan kedisiplinan adalah kesadaran dan kesediaan seseorang mentaati semua peraturan perusahaan dan norma-norma sosial yang berlaku. Kedisiplinan harus ditegakkan dalam suatu organisasi perusahaan. Tanpa dukungan disiplin karyawan yang baik, sulit bagi perusahaan untuk mewujudkan tujuannya. Jadi, kedisiplinan adalah kunci keberhasilan suatu perusahaan dalam mencapai tujuan.

Rivai (2014:559) "mendeifinisikan disiplin kerja adalah suatu alat yang digunakan para manajer untuk berkomunikasi dengan karyawan agar mereka bersedia untuk mengubah suatu perilaku serta sebagai upaya untuk meningkatkan kesadaran dan kesediaan seseorang mentaati semua peraturan perusahaan dan norma-norma sosial yang berlaku".

Simamora (2014:610) "mendefinisikan disiplin kerja adalah prosedur yang mengoreksi atau menghukum bawahan karena melanggar peraturan atau prosedur. Disiplin merupakan pengendalian diri karyawan dan pelaksanaan yang teratur dan menunjukkan tingkat kesungguhan tim kerja didalam sebuah organisasi. Tindakan 
Windi Widyalova ,Budi Rismayadi, Flora Patricia

Vol 4 No 1

ISSN : 2541-6995

E ISSN : 2580-5517

disiplin menuntut suatu hukuman terhadap karyawan yang gagal memenuhi standar yang ditetapkan. Tindakan disiplin yang efektif terpusat pada perilaku karyawan yang salah, bukan pada diri karyawan sebagai pribadi”.

Dari definisi diatas penulis mengambil kesimpulan bahwa disiplin kerja adalah suatu keasadaran seseorang dalam mentaati segala peraturan perusahaan dan norma-norma sosial yang berlaku sebgai pengendalian diri dalam pelaksanaan kerja yang teratur dalam sebuah organisasi atau perusahaan. 


\subsection{Kinerja}

Anwar Prabu Mangkunegara (2011:67) mengemukakan bahwa "kinerja yaitu hasil kerja secara kualitas dan kuantitas yang dicapai oleh seseorang karyawan dalam melaksanakan tugasnya seusai dengan tanggung jawab yang diberikan kepadanya". Sedarmayanti (2011:60) mengemukakan bahwa "kinerja merupakan terjemahan dari performance yang berarti hasil kerja seorang pekerja, sebuah proses manajemen atau organisasi secara keseluruhan, dimana hasil kerja tersebut harus dapat ditunjukkan buktinya secara konkrit dan dapat diukur". Mahsum (Masana Sembiring, 2012:81) mengatakan bahwa "kinerja adalah gambaran mengenai tingkat pencapaian pelaksanaan suatu kegiatan, program, dan kebijakan dalam mewujudkan sasaran, tujuan misi, dan visi organisasi”.

Berdasarkan pengertian-pengertian dari beberapa pendapat diatas, dapat disimpulkan bahwa kinerja merupakan hasil kerja baik itu secara kualitas maupun kuantitas yang telah dicapai karyawan, dalam menjalankan tugas-tugasnya sesuai dengan tanggung jawab dan perannya didalam perusahaan untuk mencapai tujuan perusahaan. Berhasil tidaknya suatu kinerja yang dicapai organisasi tersebut dipengaruhi kinerja karyawan secara individual maupun kelompok. Dengan asumsi semakin baik kinerja karyawan maka semakin baik kinerja suatu organisasi atau perusahaan.

\subsection{Kerangka Pemikiran}




\subsection{Hipotesis}

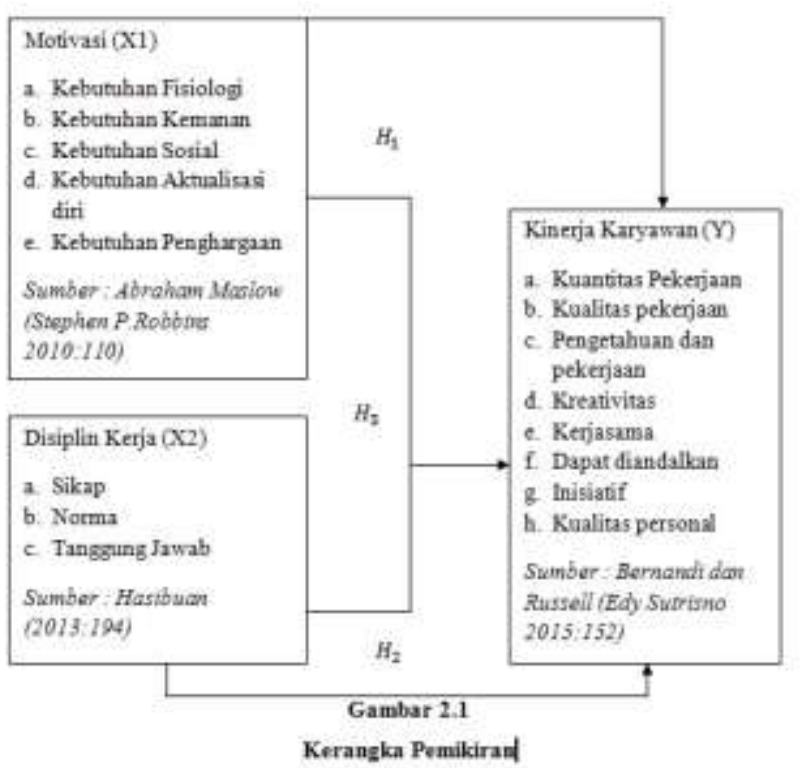

\section{Penelitian}

Menurut Sugiyono (2014:134) hipotesis merupakan jawaban sementara terhadap rumusan masalah penelitian, dimana rumusan masalah penelitian telah dinyatakan dalam bentuk kalimat pertanyaan. Dikatakan sementara, karena jawaban yang diberikan baru didasarkan pada teori yang relevan, belum didasarkan pada fakta - fakta empiris yang diperoleh melalui pengumpulan data. Berikut ini adalah rangkaian Hipotesis Penelitian :

1. Motivasi Kerja (X1) terhadap Kinerja Karyawan (Y) secara simultan berpengaruh signifikan terhadap Disiplin Kerja (X2) karyawan di Management office Resinda Park Mall Karawang.

2. Disiplin Kerja (X2) terhadap Kinerja Karyawan (Y) secara simultan berpengaruh signifikan terhadap Motivasi Kerja (X1) di Management Office Resinda Park Mall Karawang.

3. Motivasi Kerja (X1) dan Disiplin Kerja (X2) secara parsial berpengaruh signifikan terhadap Kinerja Karyawan (Y) di Management Office Resinda Park Mall Karawang.

\section{Metode Penelitian}

\subsection{Metode yang digunakan}

Penelitian ini merupakan penelitian metode kuantitatif. Menurut Sugiyono (2014:35) penelitian kuantitatif adalah metode penelitian yang berlandaskan pada 
filsafat positivisme, digunakan untuk meneliti pada populasi atau sampel tertentu, pengumpulan data menggunakan instrumen penelitian, analisis data bersifat kuantitatif atau statistik, dengan tujuan untuk menguji hipotesis yang telah ditetapkan. Jenis penelitian yang digunakan adalah penelitian Korelasi. Penelitian ini berhubungan dengan penilaian antara dua atau lebih fenomena. Jenis penelitian ini biasanya melibatkan ukuran statistic tingkat/derajat hubungan, yang disebut korelasi (Syamsudin \& Damiyanti : 2011). Metode penelitian yang digunakan adalah penelitian survey. Penelitian survey adalah penelitian yang dilakukan pada populasi besar maupun kecil.

Menurut Sugiyono (2013:13), metode penelitian kuantitatif adalah "Metode penelitian kuantitatif dapat diartikan sebagai metode penelitian yang berlandaskan pada filsafat positivisme, digunakan untuk meneliti pada populasi atau sampel tertentu, teknik pengambilan sampel pada umumnya dilakukan secara random, pengumpulan data menggunakan instrumen penelitian, analisis data bersifat kuantitatif/statistik dengan tujuan untuk menguji hipotesis yang telah ditetapkan." Dalam penelitian ini menggunakan metode survey, dimana menggunakan kuesioner sebagai instrumen utama. Teknik pengumpulan data metode survey ini, penelitian dilakukan dalam ruang alamiah atau bukan buatan dan peneliti melakukan perlakuan dalam pengumpulan data. Seperti yang dikemukakan oleh Sugiyono (2011:6) bahwa, metode survey digunakan untuk mendapatkan data dari tempat tertentu yang alamiah (bukan buatan), tetapi peneliti melakukan perlakuan dalam pengumpulan data, misalnya dengan instrumen kuesioner, test, wawancara terstruktur dan sebagainya.

\subsection{Sumber Data}

Dalam penelitian ini, data yang diteliti merupakan data primer, menurut Sugiyono (2012:402) pengertian data primer adalah "sumber data yang langsung memberikan data kepada pengumpul data". Berdasarkan sumbernya, data dibedakan menjadi dua, yaitu : Data Primer merupakan data yang diperoleh secara langsung dari hasil wawancara, observasi dan kuesioner yang disebarkan kepada sejumlah sampel responden yang sesuai dengan target sasaran dan dianggap 
mewakili seluruh populasi yang ada dalam penelitian ini yaitu Karyawan Management Office Resinda Park Mall.

\subsection{Teknik Pengumpulan Data/Informasi}

Teknik pengumpulan data dan instrument pengumpulan data merupakan faktor penting demi keberhasilan penelitian. Hal ini berkaitan dengan bagaimana cara mengumpulkan data, siapa sumbernya dan apa alat yang digunakan.

Pengumpulan data yang dilakukan dalam penelitian ini yaitu dengan menggunakan teknik sampling. Teknik sampling yang digunakan dalam penelitian ini yaitu studi kepustakaan dan studi lapangan.

1. Studi Kepustakaan adalah kegiatan untuk menghimpun informasi yang relevan dengan topik atau masalah yang menjadi objek penelitian. Dengan melakukan studi kepustakaan, peneliti dapat memanfaatkan semua informasi dan pemikiran-pemikiranyang relevan dengan penelitiannya.

2. Studi Lapangan adalah salah satu proses kegiatan pengungkapan fakta-fakta melalui observasi/pengamatan, kuesioner dan wawancara dalam proses memperoleh keterangan atau data dengan cara terjun langsung ke lapangan.

3. Wawancara, digunakan peneliti untuk melakukan studi pendahuluan untuk mengemukakan permasalahan yang harus diteliti, dan juga peneliti ingin mengetahui hal-hal dari responden yang lebih mendalam dan jumlah respondennya sedikit dengan melakukan wawancara langsung.

4. Observasi, yaitu melakukan pengamatan langsung dan mempelajari hal-hal yang berhubungan dengan peneletian secara lansung.

5. Angket (Kuesioner), yaitu dengan mngajukan pertanyaan-pertanyaan yang sudah disiapkan secara tertulis dengan menyebar angket dan disertai dengan alternatif jawaban yang akan diberikan kepada responden.

Tabel 3.3

Kriteria skala penilaian

\begin{tabular}{|c|c|}
\hline Keterangan & Bobot \\
\hline Sangat Tidak Baik & 1 \\
\hline Tidak Baik & 2 \\
\hline Baik & 3 \\
\hline Cukup Baik & 4 \\
\hline Sangat Baik & 5 \\
\hline
\end{tabular}


6. Dokumen adalah metode pengumpulan data yang tidak ditujukan langsung kepada subjek penelitian. Studi dokumen adalah jenis pengumpulan data yang meneliti berbagai macam dokumen yang berguna untuk bahan analisis.

\subsection{Teknik Penentuan Data}

Menurut Saefullah dan Sudaryono (2012:14) menyatakan bahwa berdasarkan cara memperolehnya, data dibedakan menjadi dua, yaitu :

\section{Data Primer}

Data primer yaitu data yang dikumpulkan dan diolah suatu badan atau individu secara langsung dari objeknya. Pada penelitian ini penulis menggunakan data primer berupa kuesioner. Kuesioner menurut Sugiyono (2014:230) kuesioner merupakan teknik pengumpulan data yang dilakukan dengan cara memberi seperangkat pertanyaan atau pernyataan tertulis kepada responden untuk dijawabnya.

\section{Data Sekunder}

Data sekunder yaitu data yang diperoleh dalam bentuk sudah jadi, sudah dikumpulkan dan diolah oleh pihak lain. Data sekunder pada umumnya berupa bukti, catatan atau laporan historis yang telah tersusun dalam arsip (data dokumenter) yang dipublikasikan dan yang tidak dipublikasikan. Data sekunder dapat diperoleh dari buku - buku, jurnal, internet, dan sumber bacaan lainnya yang berhubungan dengan topik yang sedang diteliti.

\section{Pembahasan}

\subsection{Karakteristik Responden Berdasarkan Usia}

Berikut ini merupakan data responden berdasarkan usia yang telah kumpulkan, yaitu : 


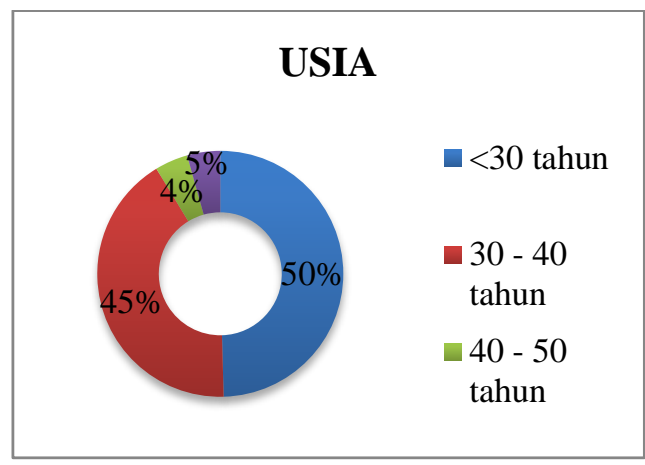

Gambar 4.2

Karakteristik Responden Berdasarkan Usia Sumber : Hasil pengolahan data, 2019

Berdasarkan gambar 4.2, dari 115 responden dapat diketahui responden yang berusia $<30$ tahun sebanyak 57 orang atau $50 \%$, responden yang berusia $30-40$ tahun sebanyak 48 orang atau $45 \%$, responden yang berusia 40 - 50 tahun sebanyak 5 orang atau $4 \%$ dan responden yang berusia $<50$ tahun sebanyak 5 orang atau $5 \%$. Dari data tersebut dapat disimpulkan bahwa pegawai di Management Office Resinda Park Mall Karawang, didominasi oleh pegawai yang berusia $<30-40$ tahun.

\subsection{Karakteristik Responden Berdasarkan Pendidikan Terakhir}

Berikut ini merupakan data responden berdasarkan pendidikan terakhir yang telah kumpulkan, yakni :

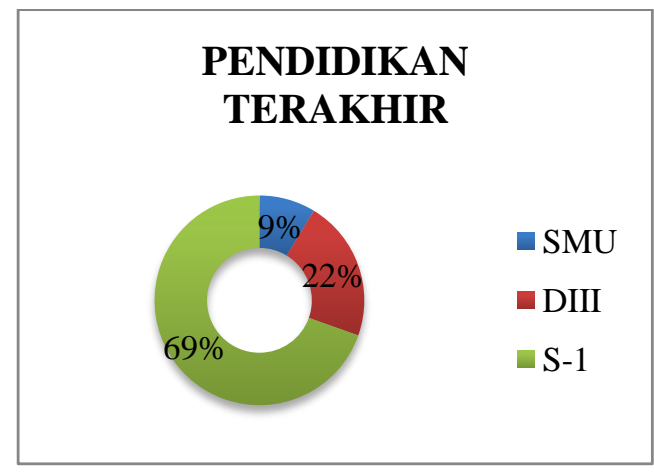

Gambar 4.3

Karakteristik Responden Berdasarkan Pendidikan Terakhir Sumber : Hasil pengolahan data, 2019

Berdasarkan gambar 4.3, dari 115 responden dapat diketahui bahwa pegawai yang berpendidikan terakhir SMU/Sederajat sebanyak 10 orang atau 9\%, pegawai yang berpendidikan terakhir DIII sebanyak 25 orang atau $22 \%$, pegawai yang 
Windi Widyalova ,Budi Rismayadi, Flora Patricia

Vol 4 No 1

ISSN : 2541-6995

E ISSN : 2580-5517

berpendidikan terakhir S-1 (Strata Satu) sebanyak 80 orang atau 69\%. Dari data tersebut dapat disimpulkan bahwa pegawai di Management Office Resinda Park Mall Karawang didominasi oleh pegawai yang berpendidikan terakhir S-1 (Strata Satu).

\subsection{Karakteristik Responden Berdasarkan Jenis Kelamin}

Berikut ini merupakan data responden berdasarkan jenis kelamin yang dikumpulkan, yakni :

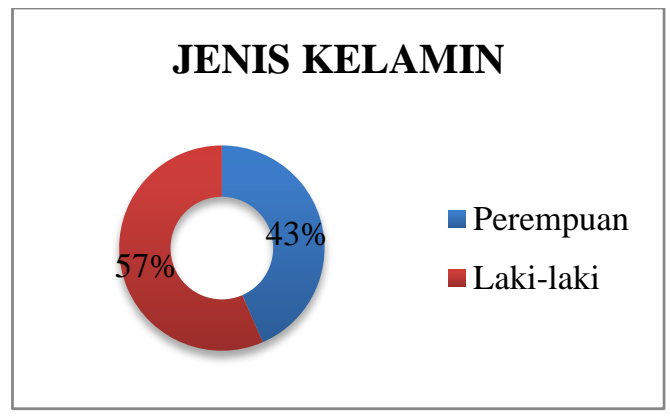

Gambar 4.4

Karakteristik Responden Berdasarkan Jenis Kelamin

Sumber : Hasil pengolahan data, 2019

Berdasarkan gambar 4.4, dari 115 responden dapat diketahui pegawai yang berjenis kelamin perempuan sebanyak 50 orang atau $43 \%$, pegawai yang berjenis kelamin Laki-laki sebanyak 65 orang atau 57\%. Dari data tersebut dapat disimpulkan bahwa pegawai di Management Office Resinda Park Mall Karawang, didominasi oleh pegawai dengan jenis kelamin Laki-laki. 
Windi Widyalova ,Budi Rismayadi , Flora Patricia

Vol 4 No 1

ISSN : 2541-6995

E ISSN : 2580-5517

Rekapitulasi Motivasi Kerja (X1)

\begin{tabular}{|c|c|c|c|}
\hline No. & Indikator & Skor & Keterangan \\
\hline 1 & Penyediaan ruang kerja yang nyaman & 472 & Baik \\
\hline 2 & Penyediaan sarana kerja yang memadai & 476 & Baik \\
\hline 3 & Penyediaan fasilitas kerja yang memadai & 471 & Baik \\
\hline 4 & $\begin{array}{l}\text { Adanya jaminan keamanan lingkungan } \\
\text { pekerjaan }\end{array}$ & 459 & Baik \\
\hline 5 & $\begin{array}{l}\text { Adanya dukungan pengamanan dalam } \\
\text { pelaksanaan kerja }\end{array}$ & 471 & Baik \\
\hline 6 & Adanya hubungan terhadap resiko pekerjaan & 467 & Baik \\
\hline 7 & $\begin{array}{l}\text { Adanya hubungan antar sesama karyawan } \\
\text { dengan baik }\end{array}$ & 487 & Sangat Baik \\
\hline 8 & $\begin{array}{l}\text { Adanya dukungan antar sesama karyawan } \\
\text { dengan baik }\end{array}$ & 509 & Sangat Baik \\
\hline 9 & $\begin{array}{c}\text { Adanya hubungan karyawan dengan atasan } \\
\text { secara baik }\end{array}$ & 512 & Sangat Baik \\
\hline 10 & Dapat bermanfaat bagi perusahaan & 492 & Sangat Baik \\
\hline 11 & $\begin{array}{c}\text { Adanya pengembangan pendidikan bagi } \\
\text { karyawan }\end{array}$ & 454 & Baik \\
\hline 12 & $\begin{array}{c}\text { Adanya pengembangan pelatihan bagi } \\
\text { karyawan }\end{array}$ & 458 & Baik \\
\hline 13 & Mendapatkan penghargaan dari atasan & 434 & Baik \\
\hline 14 & $\begin{array}{l}\text { Karyawan mendapatkan insentif dengan tepat } \\
\text { waktu }\end{array}$ & 438 & Baik \\
\hline 15 & Mendapatkan penghargaan dari perusahaan & 474 & Baik \\
\hline \multicolumn{2}{|c|}{ Total Skor } & 7074 & \multirow[t]{2}{*}{ Baik } \\
\hline & Rata-rata Skor & 471 & \\
\hline
\end{tabular}

Sumber : hasil pengolahan data, 2019

Berdasarkan tabel 4.26 total skor untuk variabel Motivasi Kerja sebesar 7.074 dengan rata-rata skor 471. Hal ini menunjukkan bahwa Motivasi Kerja di Manajemen Office Resinda Park Mall Karawang secara umum berada pada kriteria Baik, gambaran tersebut dapat dijelaskan sebagai berikut : 
ISSN : 2541-6995

E ISSN : 2580-5517

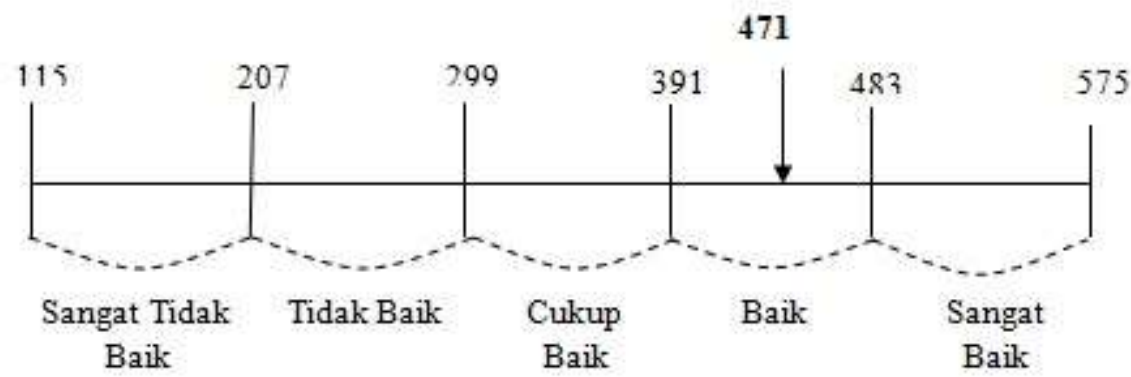

Gambar 4.20

Rekapitulasi Motivasi Kerja (X1)

Sumber: hasil pengolahaan data, 2019

Berdasarkan gambar 4.20 menunjukkan variabel Motivasi Kerja berada pada skala 391-483 dengan kriteria Baik. Artinya variabel Motivasi Kerja karyawan di Manajemen Office Resinda Park Mall Karawang sudah berjalan dengan baik.

\section{Rekapitulasi Disiplin Kerja (X2)}

\begin{tabular}{|c|c|c|c|}
\hline No. & Indikator & Skor & Keterangan \\
\hline 1 & Kahadiran karyawan dengan tepat waktu & 469 & Baik \\
\hline 2 & Datang dengan tepat waktu setelah istirahat & 467 & Baik \\
\hline 3 & Bisa disiplin waktu sesuai peraturan perusahaan & 467 & Baik \\
\hline 4 & Pulang kerja dengan tepat waktu & 503 & Sangat Baik \\
\hline 5 & $\begin{array}{l}\text { Menggunakan peralatan sesuai dengan } \\
\text { kebutuhan }\end{array}$ & 478 & Baik \\
\hline 6 & $\begin{array}{l}\text { Memanfaatkan perlengkapan yang ada } \\
\text { sebagaimana mestinya }\end{array}$ & 465 & Baik \\
\hline 7 & Dapat mematuhi peraturan kerja yang berlaku & 452 & Baik \\
\hline 8 & Berpakaian sesuai dengan aturan yang berlaku & 491 & Sangat Baik \\
\hline 9 & Mengikuti cara kerja sesuai dengan petunjuk & 461 & Baik \\
\hline 10 & Dapat menjalankan tugas perusahaan & 463 & Baik \\
\hline 11 & Dapat mematuhi perintah atasan & 482 & Baik \\
\hline 12 & Dapat mentaati peraturan perusahaan & 494 & Sangat Baik \\
\hline
\end{tabular}


E ISSN : 2580-5517

\begin{tabular}{|c|l|c|c|}
\hline 13 & $\begin{array}{l}\text { Dapat menyelesaikan pekerjaan dengan tepat } \\
\text { waktu }\end{array}$ & 473 & Baik \\
\hline
\end{tabular}

Rekapitulasi Disiplin Kerja (X2) Lanjutan

\begin{tabular}{|c|l|c|c|}
\hline No. & \multicolumn{1}{|c|}{ Indikator } & Skor & Keterangan \\
\hline 14 & $\begin{array}{l}\text { Dapat bertanggung jawab terhadap tugasnya } \\
\text { masing-masing }\end{array}$ & 467 & Baik \\
\hline 15 & Dapat berkomitmen & 500 & Sangat Baik \\
\hline \multicolumn{2}{r|}{ Total Skor } & 7132 & Baik \\
\hline \multicolumn{2}{r|}{ Rata-rata Skor } & 475 & \\
\hline
\end{tabular}

Sumber : hasil pengolahan data, 2019

Berdasarkan tabel 4.42 total skor untuk variabel Disiplin Kerja sebesar 7.132 dengan rata-rata skor 475. Hal ini menunjukkan bahwa Disiplin Kerja di Manajemen Office Resinda Park Mall Karawang secara umum berada padakriteria Baik, gambaran tersebut dapat dijelaskan sebagai berikut :

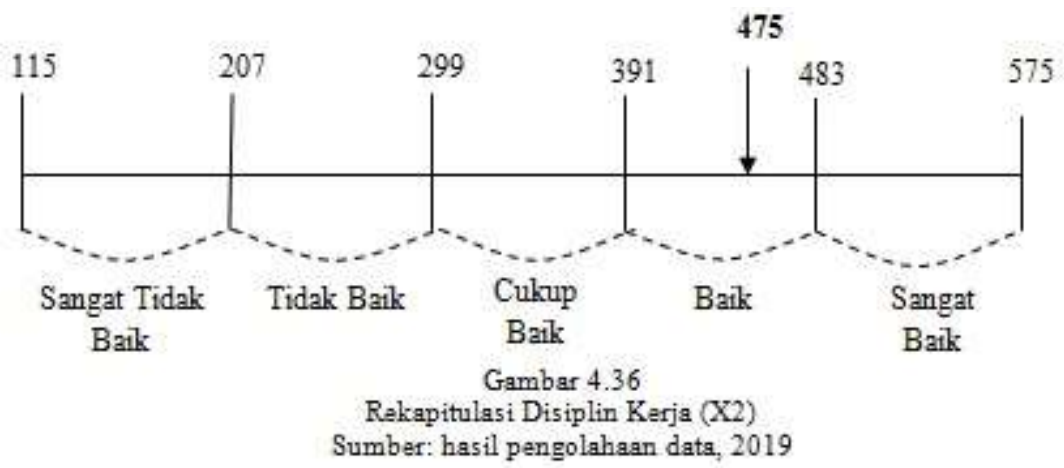

Berdasarkan gambar 4.36 menunjukkan variabel Disiplin Kerja berada pada skala 391-483 dengan kriteria Baik. Artinya variabel Disiplin Kerja karyawan di Manajemen Office Resinda Park Mall Karawang sudah berjalan dengan baik.

\section{Rekapitulasi Kinerja Karyawan (Y)}

\begin{tabular}{|c|l|c|c|}
\hline No. & \multicolumn{1}{|c|}{ Indikator } & Skor & Keterangan \\
\hline 1 & $\begin{array}{l}\text { Pelaksanaan tugas dengan baik oleh para } \\
\text { pegawai }\end{array}$ & 482 & Baik \\
\hline 2 & $\begin{array}{l}\text { Pelaksanaan tugas dengan tepat waktu oleh } \\
\text { para pegawai }\end{array}$ & 449 & Baik \\
\hline 3 & Dapat menimbulkan kepuasan bagi pimpinan & 456 & Baik \\
\hline
\end{tabular}


Windi Widyalova ,Budi Rismayadi , Flora Patricia

Vol 4 No 1

ISSN : 2541-6995

E ISSN : 2580-5517

\begin{tabular}{|c|c|c|c|}
\hline 4 & Dapat menimbulkan kepuasan bagi rekan kerja & 452 & Baik \\
\hline
\end{tabular}

Rekapitulasi Kinerja Karyawan (Y) Lanjutan

\begin{tabular}{|c|c|c|c|}
\hline No. & Indikator & Skor & Keterangan \\
\hline 5 & $\begin{array}{l}\text { Dapat memahami pengetahuan tugas dengan } \\
\text { cepat }\end{array}$ & 464 & Baik \\
\hline 6 & $\begin{array}{l}\text { Dapat memahami pengetahuan prosedur } \\
\text { dengan cepat }\end{array}$ & 470 & Baik \\
\hline 7 & $\begin{array}{l}\text { Dapat memberikan sumbangan ide bagi rekan } \\
\text { kerja dan perusahaan }\end{array}$ & 498 & Sangat Baik \\
\hline 8 & $\begin{array}{l}\text { Dapat memberikan sumbangan saran bagi } \\
\text { rekan kerja dan perusahaan }\end{array}$ & 477 & Baik \\
\hline 9 & $\begin{array}{l}\text { Dapat melakukan kerjasama dengan rekan } \\
\text { kerja }\end{array}$ & 516 & Sangat Baik \\
\hline 10 & $\begin{array}{l}\text { Dapat melakukan kerjasama dengan } \\
\text { perusahaan }\end{array}$ & 505 & Sangat Baik \\
\hline 11 & $\begin{array}{l}\text { Dapat mengenali masalah dilingkungan } \\
\text { pekerjaan }\end{array}$ & 444 & Baik \\
\hline 12 & $\begin{array}{l}\text { Dapat memahami masalah dilingkungan } \\
\text { pekerjaan }\end{array}$ & 490 & Sangat Baik \\
\hline 13 & $\begin{array}{l}\text { Dapat menyelesaikan persoalan dengan } \\
\text { tanggap }\end{array}$ & 478 & Baik \\
\hline 14 & $\begin{array}{l}\text { Mempunyai hubungan kerja yang baik dengan } \\
\text { pimpinan }\end{array}$ & 458 & Baik \\
\hline 15 & $\begin{array}{l}\text { Mempunyai hubungan kerja yang baik dengan } \\
\text { rekan kerja }\end{array}$ & 501 & Sangat Baik \\
\hline
\end{tabular}

Sumber : hasil pengolahan data, 2019

Berdasarkan tabel 4.58 total skor untuk variabel Disiplin Kerja sebesar 7.140 dengan rata-rata skor 476. Hal ini menunjukkan bahwa Kinerja Karyawan di Manajemen Office Resinda Park Mall Karawang secara umum berada pada kriteria Baik, gambaran tersebut dapat dijelaskan sebagai berikut : 
Windi Widyalova ,Budi Rismayadi, Flora Patricia

Vol 4 No 1

ISSN : 2541-6995

E ISSN : 2580-5517

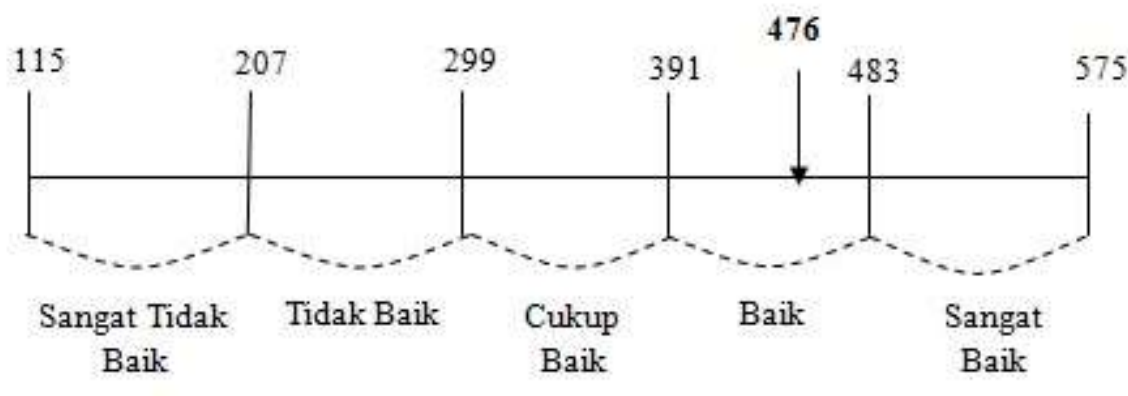

Gambar 4.52

Rekapitulasi Kinerja Karyawan (Y)

Sumber: hasil pengolahaan data, 2019 
Berdasarkan gambar 4.52 menunjukkan variabel Disiplin Kerja berada pada skala 391-483 dengan kriteria Baik. Artinya variabel Kinerja karyawan di Manajemen Office Resinda Park Mall Karawang sudah berjalan dengan baik.

\section{Kesimpulan dan Saran}

\subsection{Kesimpulan}

Berdasarkan penelitian yang telah dilakukan mengenai pengaruh motivasi kerja dan disiplin kerja terhadap kinerja karyawan di management office resinda park mall karawang, dapat diambil beberapa kesimpulan yang diharapkan dapat memberikan jawaban terhadap permasalahan yang dirumukan dalam penelitian ini, yaitu sebagai berikut :

1. Motivasi kerja (X1) di Management Office Resinda Park Mall Karawang dianggap baik karena memiliki skor rata-rata 471 pada rentang skala 391-483. maka secara keseluruhan mtoivasi kerja di management office reisnda park mall karawang sudah termasuk dalam kategori baik.

2. Disiplin kerja (X2) di Management Office Resinda Park Mall Karawang dianggap baik karena memiliki skor rata-rata 475 pada rentang skala 391-483. maka secara keseluruhan disiplin kerja di management office reisnda park mall karawang sudah termasuk dalam kategori yang baik.

3. Berdasarkan hasil uji analisis deskriptif, variabel kinerja karyawan (Y) dianggap baik karena memiliki skor rata-rata 476 pada rentang skala 391-483. maka secara keseluruhan kinerja karyawan di management office reisnda park mall karawang sudah termasuk dalam kategori yang baik.

4. Hubungan diantara variabel bebas yaitu antara Motivasi dan Disiplin Kerja menunjukan korelasi sebesar 0,667. Menunjukan bahwa Motivasi dan Disiplin Kerja mempunyai hubungan yang kuat.

5. Terdapat pengaruh Motivasi dan Disiplin Kerja secara parsial terhadap Kinerja Karyawan dengan rincian sebagai berikut :

a. Pengaruh Motivasi secara parsial terhadap Kinerja Karyawan adalah sebesar 0,596 atau $59,6 \%$.

b. Pengaruh Disiplin Kerja Terhadap Kinerja Karyawan adalah sebesar 0,513 atau 51,3\%. Karena 59,6,0\% lebih kecil dari 51,3\%, maka dapat dinyatakan 
bahwa Motivasi lebih banyak memberikan kontribusi terhadap Kinerja Karyawan dibandingkan dengan Displin Kerja.

6. Terdapat pengaruh Motivasi dan Disiplin Kerja secara simultan terhadap Kinerja Karyawan sebesar 1,109. Demikian dapat dismpulkan bahwa Motivasi dan Disiplin Kerja memiliki pengaruh terhadap Kinerja Karyawan sebesar 0,596 atau $51,3 \%$, sedangkan sisanya 53,2\% merupakan kontribusi variabel lain yang tidak diteliti.

\subsection{Saran}

\subsubsection{Saran bagi Perusahaan}

Berdasarkan hasil penelitian dan pembahasan, penulis dapat memberikan saran sebagai berikut :

1. Motivasi kerja merupakan salah satu faktor yang dapat mempengaruhi kinerja. Oleh sebab itu, disarankan pimpinan di Management Office Resinda Park Mall Karawang, hendaknya terus meningkatkan, memperhatikan serta selalu memberi motivasi kepada karyawannya agar karyawan dapat meningkatkan kinerjanya. Dengan cara memenuhi kebutuhan penunjang karyawan dan meningkatkan suasana di kantor.

2. Disiplin Kerja pada Management Office Resinda Park Mall Karawang telah berjalan dengan baik, akan tetapi masih ada indikator yang masih berada di bawah rata-rata. Untuk meningkatkan Disiplin Kerja disarankan sebaiknya perusahaan lebih tegas kepada karyawan agar karyawan dapat bertanggung jawab terhadap pekerjaannya.

3. Kinerja Karyawan pada Management Office Resinda Park Mall Karawang telah berjalan dengan baik, akan tetapi masih ada indikator yang masih berada di bawah rata-rata seperti hubungan baik. Untuk meningkatkan Kinerja Karyawan disarankan sebaiknya perusahaan dan karyawan memiliki hubungan yang baik agar kinerja karyawan lebih maksimal.

4. Agar pihak perusahaan dapat terus meningkatkan kinerja karyawan dan dapat mempertahankan apa yang telah dicapai selama ini, dengan cara memperhatikan kualitas dan kuantitas yang dicapai, disiplin, kerjasama para karyawannya. 


\subsubsection{Saran bagi Peneliti Selanjutnya}

1. Peneliti selanjutnya diharapkan dapat melakukan penelitian yang lebih baik dan terinci agar setiap masalah dalam perusahaan yang diteliti dapat terpecahkan dan bermanfaat bagi perusahaan yang diteliti.

2. Peneliti selanjutnya diharapkan untuk meneliti variabel lain yang tidak diteliti dalam penelitian ini yang berpengaruh terhadap Kinerja Karyawan

3. Peneliti selanjutnya diharapkan untuk mencoba menggunakan metode lain dalam penelitiannya agar tidak menimbulkan kejenuhan dalam penelitian.

\section{Daftar Pustaka}

Arikunto, Suharsimi, 1995, Manajemen Penelitian, Rineka Cipta, Jakarta.

Arikunto, Suharsimi, 2002, Prosedur Penelitian suatu Pendekatan Praktek, Edisi Revisi V Cetakan Kedua belas, BandungRineka Cipta.

Badriyah, Mila. 2015. Manajemen Sumber Daya Manusia, Cetakan ke satu. Bandung

Djarwanto PS. 1988. Statistik Induktif Edisi ketiga.Yogyakarta: BPFE Yogyakarta Djarwanto dan Pangestu Subagyo. 1996. Statistik induksi Edisi ketiga. Yogyakarta:BPFE. Ghozali Imam. 2002. Aplikasi SPSS. Semarang. BP Universitas Diponegoro.

Guritno, Bambang dan Waridin.2005. Pengaruh Persepsi Karyawan Mengenai Perilaku Kepemimpinan, Kepuasan Kerja Dan Motivasi Terhadap Kinerja. JRBI. Vol 1. No 1. Hal: 63-74.

Hakim, Abdul. 2006. Analisis Pengaruh Motivasi, Komitmen Organisasi Dan Iklim Organisasi Terhadap Kinerja Pegawai Pada Dinas Perhubungan Dan Telekomunikasi Provinsi Jawa Tengah. JRBI. Vol 2. No 2. Hal: 165-180.

Handoko BS, 2001, Pemikiran Pendekatan Pembangunan di Awal Millennium: Penekananpada Kualitas Pertumbuhan, Jurnal Ekonomi Pembangunan - Kajian Ekonomi Negara Berkembang: Yogyakarta: Fakultas Ekonomi. Universitas Islam Indonesia. Volume 6,Nomor 2.

Handoko, T. Hani 2000. Manajemen Personalia dan Sumber Daya Manusia, BPFEUGM, Yogyakarta.

Handoko, T. Hani. 2002. Manajemen Edisi 1. BPFE. Yogyakarta. 
Windi Widyalova ,Budi Rismayadi, Flora Patricia

Vol 4 No 1

ISSN : 2541-6995

E ISSN : 2580-5517

Hasibuan, Melayu, 2017. Manajemen Sumber Daya Manusia, Cetakan ke satu. Bandung

Hasibuan, Malayu. 2004. Manajemen Sumber Daya Manusia. PT Bumi Aksara. Jakarta.

Masrukhin dan Waridin. 2004. Pengaruh Motivasi Kerja, Kepuasan Kerja, Budaya Organisasi Dan Kepemimpinan Terhadap Kinerja Pegawai. EKOBIS. Vol 7. No 2.Hal: 197-209.

MC. Clelland, Atkinto, Clark dan Lowell,1953. The Achievement Motiv, New York: Appeton-Century-Cofts.

Richard M Steers. 2011. Motivation and Work Behavior. Fifth Edition. New York: McGraw-Hill.

Rismayadi Budi 2018 Mediasi Komitmen Organisasi dalam meningkatkan Kinerja Karyawan PT. Perkebunan Nusantara VIII Provinsi Jawa Barat. Jurnal $\begin{array}{llllll}\text { Manajemen dan } & \text { Bisnis } & \text { Kreatif, } & \text { Vol } & 4 & \text { No.1 }\end{array}$ http://journal.ubpkarawang.ac.id/index.php/Manajemen/article/view/386

Rismayadi Budi, Hasbi WH. 2018. Peran Kepemimpinan dan Motivasi terhadap Kinerja Karyawan PT. Taiho Nusantara, Value Journal of Management and Business Vol. 2 No. 2 https://journal.unsika.ac.id/index.php/value/article/view/1329

Rismayadi Budi 2017. The influence of organizational culture, soft skills and leadership on organizational commitment and its implication at educator performance (empirical research on community learning center Karawang District, West Java Province. International Journal of Applied Business and Economic Research, Vol. 15 No. 20. Pp 111 - 131

Rivai, Veithzal. 2004. Manajemen Sumber Daya Manusia Untuk Perusahaan. PT RAJA GRAFINDO PERSADA. Jakarta.

Rivai, Veithzal. 2005. Manajemen Sumber Daya Manusia”. Jakarta: CV Haji Masagi.

Rivai, Veithzal dan Basri. 2005. Performance Appraisal: Sistem Yang Tepat Untuk Menilai Kinerja Karyawan Dan Meningkatkan Daya Saing Perusahaan. PT RAJAGRAFINDO PERSADA. Jakarta.

Simamora, Henry. 1997. Manajemen Sumber Daya Manusia. STIE YKPN. Yogyakarta.

Singgih, Santosa. 2000. SPSS Statistik Parametrik, Jakarta : PT Elex Media Komputindo.

Sugiyono, 2010, Metodologi Penelitian Kuantitatif, Bandung : Alfabeta. Tika, P. 2006. Budaya Organisasi Dan Peningkatan Kinerja Perusahaan. PT Bumi Aksara. Jakarta. 
Windi Widyalova ,Budi Rismayadi, Flora Patricia

Vol 4 No 1

ISSN : 2541-6995

E ISSN : 2580-5517

Saleha. 2016. "Pengaruh Lingkungan Kerja, Etos Kerja dan Budaya Kerja terhadap Kinerja Pegawai pada Dinas Bina Marga Propinsi Sulawesi Tengah”. Jurnal Katalogis, Vol. 4, No 3, p 196-203

Badriyah, Mila. 2015. Manajemen Sumber Daya Manusia, Cetakan ke satu. Bandung

Handoko T. Hani. 2011. Manajemen. Yogyakarta: BPFE

Hasibuan, Malayu, 2017. Manajemen Sumber Daya Manusia, Edisi Revisi. Jakarta 